\title{
A Paleo Perspective of Alabama and Florida (USA) Interstate Streamflow
}

\author{
Melanie Vines ${ }^{1}{ }^{\circledR}$, Glenn Tootle ${ }^{1}$, Leigh Terry ${ }^{1}{ }^{\circledR}$, Emily Elliott ${ }^{2}$, Joni Corbin ${ }^{1}$, Grant L. Harley ${ }^{3}{ }^{(}$, \\ Jonghun Kam $\left.{ }^{4}{ }^{(}\right)$, Sahar Sadeghi ${ }^{1}$ and Matthew Therrell ${ }^{2, *}$
}

\section{check for}

updates

Citation: Vines, M.; Tootle, G.; Terry, L.; Elliott, E.; Corbin, J.; Harley, G.L.; Kam, J.; Sadeghi, S.; Therrell, M. A Paleo Perspective of Alabama and Florida (USA) Interstate Streamflow. Water 2021, 13, 657. https://doi.org/ 10.3390/w13050657

Received: 23 January 2021

Accepted: 24 February 2021

Published: 28 February 2021

Publisher's Note: MDPI stays neutral with regard to jurisdictional claims in published maps and institutional affiliations.

Copyright: (c) 2021 by the authors. Licensee MDPI, Basel, Switzerland. This article is an open access article distributed under the terms and conditions of the Creative Commons Attribution (CC BY) license (https:// creativecommons.org/licenses/by/ $4.0 /)$.
1 Department of Civil, Construction, and Environmental Engineering, University of Alabama, Tuscaloosa, AL 35487, USA; mgvines@crimson.ua.edu (M.V.); gatootle@eng.ua.edu (G.T.); leigh.terry@eng.ua.edu (L.T.); jcorbin@crimson.ua.edu (J.C.); stabatabaeisadeghi@crimson.ua.edu (S.S.)

2 Department of Geography, University of Alabama, Tuscaloosa, AL 35487, USA; emily.elliott@ua.edu

3 Department of Geography and Geological Sciences, University of Idaho, Moscow, ID 83844, USA; gharley@uidaho.edu

4 Division of Environmental Science and Engineering, Pohang University of Science and Technology (POSTECH), Pohang 37673, Korea; jhkam@postech.ac.kr

* Correspondence: therrell@ua.edu

\begin{abstract}
Seasonal reconstructions of streamflow are valuable because they provide water planners, policy makers, and stakeholders with information on the range and variability of water resources before the observational period. In this study, we used streamflow data from five gages near the Alabama-Florida border and centuries-long tree-ring chronologies to create and analyze seasonal flow reconstructions. Prescreening methods included correlation and temporal stability analysis of predictors to ensure practical and reliable reconstructions. Seasonal correlation analysis revealed that several regional tree-ring chronologies were significantly correlated $(p \leq 0.05)$ with March-October streamflow, and stepwise linear regression was used to create the reconstructions. Reconstructions spanned 1203-1985, 1652-1983, 1725-1993, 1867-2011, and 1238-1985 for the Choctawhatchee, Conecuh, Escambia, Perdido, and Pascagoula Rivers, respectively, all of which were statistically skillful $\left(R^{2} \geq 0.50\right)$. The reconstructions were statistically validated using the following parameters: $R^{2}$ predicted validation, the sign test, the variance inflation factor (VIF), and the Durbin-Watson (D-W) statistic. The long-term streamflow variability was analyzed for the Choctawhatchee, Conecuh, Escambia, and Perdido Rivers, and the recent (2000s) drought was identified as being the most severe in the instrumental record. The 2000s drought was also identified as being one of the most severe droughts throughout the entire reconstructed paleo-record developed for all five rivers. This information is vital for the consideration of present and future conditions within the system.
\end{abstract}

Keywords: drought; streamflow; hydroclimate; dendrochronology; paleoclimatology; water resources

\section{Introduction}

Tree-ring based reconstructions of streamflow are advantageous to water planners and policy makers because they extend gage records beyond the observational period, which in turn provides a better understanding of the full range of natural flow variability and the associated climatic drivers within the hydrological system. However, to develop a reliable model of past streamflow conditions, the accuracy and length of the streamflow gage records are crucial for both validating and bias correcting the reconstructed values to that of the observed period. Although the United States Geological Survey (USGS) streamflow-gaging program began collecting streamflow data as early as $1887 \mathrm{CE}$, many gages lack continuous records [1-3]. Most streamflow gage data for rivers unimpaired by human activity consist of 60 years of data or fewer, which fails to capture the full range of climate variability, therefore limiting the reliability of the overall modeled streamflow. Tree-ring chronologies (TRCs) often date back centuries and are used as a surrogate for 
hydroclimate data reconstruction to provide further historical insight [4-9], as certain tree species are sensitive to the moisture signal of the region and serve as robust proxies for streamflow reconstruction [2,8-15].

While dendrochronological reconstructions of hydroclimate, including streamflow, have been widely utilized in the western United States (US) due to the arid, moisturelimited environment $[6,7,16-28]$, until recently, similar studies have been relatively limited in the southeastern US [3,8,14,29-34]. However, Crockett et al. [2] established TRCs to be useful and statistically significant proxies even in the humid subtropical climate of northern Florida. For another example, Harley et al. [14] demonstrated a strong reconstruction of streamflow in the Suwannee River over the period of 1550-2005 CE. Furthermore, multiple studies have utilized streamflow variability in the Southeast to identify hydroclimatic extremes (i.e., floods and droughts) and the associated climatic drivers (e.g., Atlantic Multi-decadal Oscillation (AMO), El Nino-Southern Oscillation (ENSO), Pacific Decadal Oscillation (PDO)) of such events [1,35-43].

Water management has reached a critical point in the State of Florida. Recent estimates place Florida as the third most populous state in the US, and current water supply is insufficient to support the growing population of nearly $22 \mathrm{M}$ residents, not to mention the millions of visitors each year [44]. Additionally, there has been an ongoing legal conflict regarding water supplies between the states of Alabama, Florida, and Georgia (the Tri-State Water Wars) since the 1980s CE [45]. With the compounding impacts of climate change and rising temperatures on drought frequency [46], interstate water policy conflict, and agricultural growth influencing fresh water supply, paleo-perspectives of the range and variability of Florida's rivers are critical to develop best management practices that meet the growing demands of water resources.

The objective of this study is to reconstruct streamflow at five different streamflow gages near the Alabama-Florida state border and to evaluate the severity of a recent decadal drought from a centennial-scale perspective. Tree-ring chronologies from the surrounding region were used to reconstruct streamflow for the following rivers: the Choctawhatchee River near Newton, AL, the Choctawhatchee River near Bruce, FL, the Conecuh River, the Escambia River, the Perdido River and the Pascagoula River (Figure 1). These intrastate hydrological reconstructions across multiple interstate borders of the northern Gulf of Mexico coast provide valuable information regarding the water availability and urban population growth in these areas, while also highlighting the need for additional TRCs and intrastate streamflow reconstructions throughout the region.

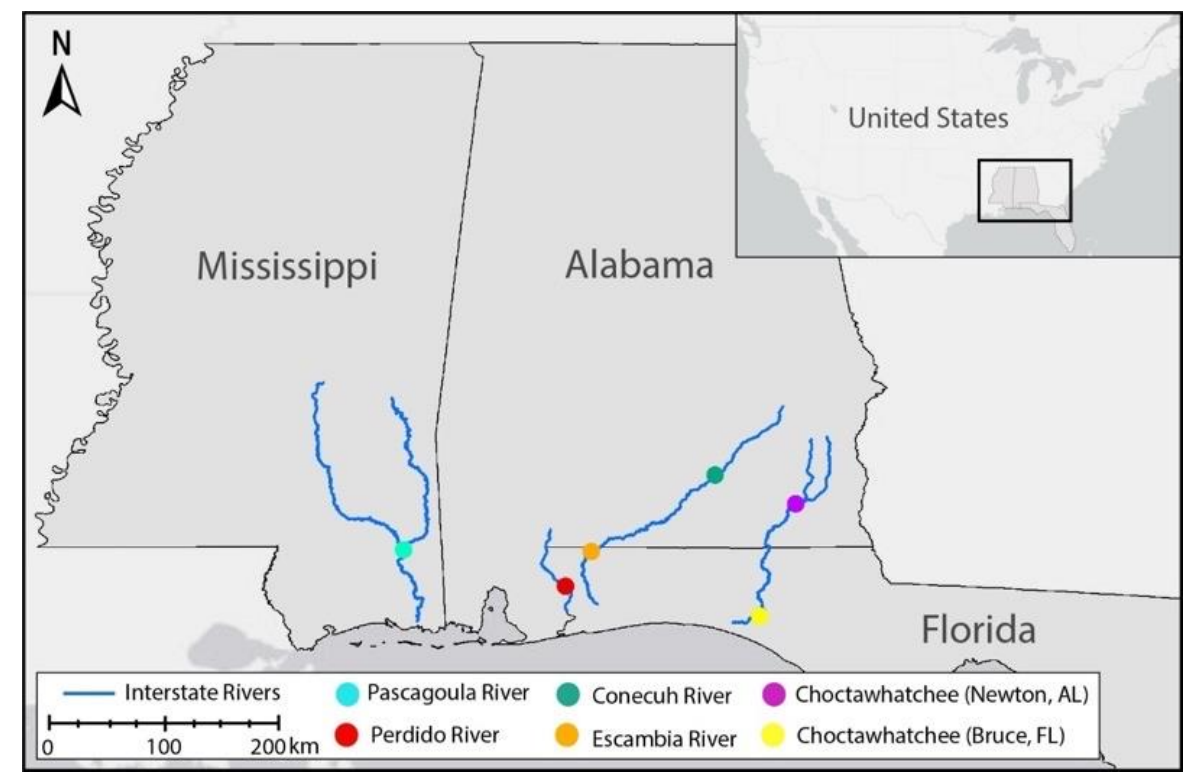

Figure 1. Location map with inset of study location within the overall United States (small black rectangle) and the six United States Geological Survey (USGS) streamflow gages used within the study between the states of Mississippi, Alabama and Florida. 


\section{Materials and Methods}

\subsection{Streamflow Data}

Streamflow data for five gages near the Alabama-Florida border and one gage near the Mississippi-Alabama border for regional comparison were obtained from the United States Geological Survey (USGS) website, via the National Water Information System (http:/ / waterdata.usgs.gov/nwis/sw (accessed on 16 June 2020)) [47]. The USGS gages contained minimal missing data and had an acceptable record to calibrate with treering chronologies from the region. The gages presented in this study are located on the Choctawhatchee River (near Newton, AL and Bruce, FL), the Conecuh River, the Escambia River, and the Perdido River (Figure 1; Table 1). These rivers are located in or near the panhandle region of Florida and constitute important streamflow systems in the region. The Conecuh River flows into the Escambia River, and the Choctawhatchee gage in Newton, AL is upstream of the gage in Bruce, FL, making the streamflow patterns in these gages highly correlated. Additionally, the nearby Pascagoula River in Mississippi was investigated for regional comparison. Monthly cumulative flow in million cubic meters (MCM) was used.

Table 1. Descriptions of the United States Geological Service (USGS) streamflow gages used for reconstruction.

\begin{tabular}{cccccc}
\hline Station Name & Station ID & Latitude & Longitude & $\begin{array}{c}\text { Drainage Area } \\
\mathbf{( k m}^{\mathbf{2}} \mathbf{m}\end{array}$ & Period of Record \\
& & & & & \\
\hline Choctawhatchee River (Newton, AL) & 02361000 & $31^{\circ} 20^{\prime} 34^{\prime \prime} \mathrm{N}$ & $85^{\circ} 36^{\prime} 38^{\prime \prime} \mathrm{W}$ & 1777 & $1936-2016$ \\
Choctawhatchee River (Bruce, FL) & 02366500 & $30^{\circ} 27^{\prime} 03^{\prime \prime} \mathrm{N}$ & $85^{\circ} 3^{\prime} 54^{\prime \prime} \mathrm{W}$ & 11,355 & $1931-1982$ \\
Conecuh River (Brantley, AL) & 02371500 & $31^{\circ} 34^{\prime} 24^{\prime \prime} \mathrm{N}$ & $86^{\circ} 15^{\prime} 06^{\prime \prime} \mathrm{W}$ & 1295 & $1938-2015$ \\
Escambia River (Century, FL) & 02375500 & $30^{\circ} 57^{\prime} 54^{\prime \prime} \mathrm{N}$ & $87^{\circ} 14^{\prime} 03^{\prime \prime} \mathrm{W}$ & 9886 & $1935-2018$ \\
Perdido River (Barrineau Park, FL) & 02376500 & $30^{\circ} 41^{\prime} 25^{\prime \prime} \mathrm{N}$ & $87^{\circ} 26^{\prime} 25^{\prime \prime} \mathrm{W}$ & 1020 & $1942-2017$ \\
Pascagoula River (Merrill, MS) & 02479000 & $30^{\circ} 58^{\prime} 40^{\prime \prime} \mathrm{N}$ & $88^{\circ} 43^{\prime} 35^{\prime \prime} \mathrm{W}$ & 17,068 & $1931-2019$ \\
\hline
\end{tabular}

\subsection{Tree Ring Chronologies}

Seventy-four "standard" TRCs from within and around the Southeastern US were used in our initial analyses. Data for 60 of these were downloaded from the International Tree-Ring Data Bank (https: / / www.ncdc.noaa.gov / data-access / paleoclimatology-data / datasets / tree-ring (accessed on 20 June 2020)) [48], which is maintained by the National Oceanic and Atmospheric Administration (NOAA) Paleoclimatology Program, and an additional 14 records were developed by the authors or provided by other researchers. Chronologies were developed as described in Harley et al. [14]. In addition to year-to-year comparison, all TRCs were shifted forward one year to account for streamflow records correlating with tree ring growth in the following year [49], denoted by a " +1 ", and the 74 lagged TRCs were used in analysis for a total of 148 TRC variables.

\subsection{Predictor Prescreening Methods}

Two prescreening methods were used to identify the most suitable TRCs to use as predictors for the reconstruction models. We selected the spring to early fall (MarchOctober; $\mathrm{M}-\mathrm{O}$ ) period of streamflow to analyze, as it has been found to be optimal for streamflow-TRC correlation in the Southeastern US [14]. During the M-O season, the bulk of streamflow recharge in this region is due to rainfall associated with cold fronts, convective thunderstorms, and tropical cyclone activity [14]. The overlapping time periods for M-O streamflow and all 148 TRCs $(t$ and $t+1)$ were correlated using Minitab, and the TRCs with positive, significant R-values $(p \leq 0.05)$ were retained. This initial calibration period stretched from the first year of streamflow data to the earliest end date of an included TRC. As statistically insignificant TRCs were eliminated, the calibration period changed to reflect the end date of the retained TRCs. This correlation was performed repeatedly with retained TRCs while adjusting the calibration period as necessary until it remained stable.

The second pre-screening method involved temporal stability analysis, per Biondi and Waikul [50], which consisted of performing correlation over 30-year moving windows between the various streamflow seasons and the chronologies identified (retained) by 
the first pre-screening analysis. No chronologies were found to contain negative 30-year correlation values with seasonal flow; therefore, all first pre-screening method retained TRCs were considered and were retained for this analysis. Stability analysis ensures that reliable and practical streamflow reconstructions are generated.

\subsection{Reconstruction Methodology}

Because all the available TRCs end before the currently available gage data (Table 2), model calibration windows were controlled by the date that streamflow data were first collected at each gage and the end date of each TRC. The beginning dates of the calibration windows ranged from 1931 to 1942 CE (Table 1), and the end dates ranged from 1983 to 2011 CE (Table 3). The statistical fitness of the TRCs to estimate streamflow was tested using a forward and backward (standard) stepwise regression model using Minitab.

Table 2. Tree-ring chronologies (TRCs) retained in streamflow reconstruction models.

\begin{tabular}{cccccc}
\hline Code & ITRDB Code & Chronology & State & Species & Chronology Length \\
\hline CHK $_{\text {EW }}$ & FL001 & Choctawhatchee Earlywood [33,51] & FL & TADI & $920-2014$ \\
CHK & FL001 & Choctawhatchee Total Ringwidth [33,51] & FL & TADI & $920-2014$ \\
EBE & GA003 & Ebenezer Creek Total Ringwidth [52] & GA & TADI & $990-1985$ \\
OCM $_{1}$ & GA004 & Ocmulgee River Total Ringwidth +1 [53] & GA & TADI & $1203-1985$ \\
SKY & MS003 & Sky Lake Swamp Total Ringwidth [54] & MS & TADI & $1238-2010$ \\
PNC $_{1}$ & TN005 & Piney Creek Total Ringwidth +1 [55] & TN & QUAL & $1652-1983$ \\
SUW & FL005 & Suwannee River Total Ringwidth +1 [56] & FL & QULY & $1725-1993$ \\
IOL $_{1}$ & TBD & Iola Lake Total Ringwidth +1 [57] & FL & NYOG & $1867-2011$ \\
PAS & MS002 & Pascagoula River Total Ringwidth [58] & MS & TADI & $1540-2014$ \\
\hline
\end{tabular}

Note: " +1 " = tree ring growth in the following year; TADI = Taxodium distichum L. Rich. (bald cypress); QUAL = Quercus alba L. (white oak); QULY = Quercus lyrata Walter (overcup oak); NYOG Nyssa Ogeche L. Ogeechee Tupelo (ITRDB = International Tree Ring Databank [51]).

Table 3. March-October streamflow reconstruction statistics and standard tree-ring chronologies (TRCs) used in each model.

\begin{tabular}{|c|c|c|c|c|c|c|c|c|}
\hline Gage & $\begin{array}{c}\text { Reconstruction } \\
\text { Period }\end{array}$ & $R^{2}(p)$ & $\mathbf{R}^{2}$ & $\mathbf{R}^{2}$ adj & VIF & D-W & $\begin{array}{c}\text { Sign } \\
\text { Test }+/-\end{array}$ & TRCs Retained \\
\hline Choctawhatchee at Newton & $1203-1985$ & 0.48 & 0.56 & 0.54 & 1.0 & 2.2 & $26 / 24$ & $\mathrm{EBE}, \mathrm{CHK}, \mathrm{OCM}_{1}$ \\
\hline Choctawhatchee at Bruce & $1238-1983$ & 0.47 & 0.51 & 0.49 & 1.2 & 2.3 & $24 / 28$ & SKY, CHK \\
\hline Conecuh & $1652-1983$ & 0.41 & 0.51 & 0.49 & 1.1 & 2.1 & $23 / 23$ & $\mathrm{PNC}_{1} \mathrm{CHK}_{\mathrm{EW}}, \mathrm{OCM}_{1}$ \\
\hline Escambia & $1725-1993$ & 0.48 & 0.57 & 0.55 & 1.2 & 1.9 & $30 / 29$ & $\mathrm{CHK}_{\mathrm{EW}}, \mathrm{SUW}, \mathrm{SKY}$ \\
\hline Perdido & $1867-2011$ & 0.43 & 0.50 & 0.49 & 1.1 & 2.0 & $39 / 31$ & $\mathrm{CHK}_{\mathrm{EW}}, \mathrm{IOL}_{1}$ \\
\hline Pascagoula & 1238-1985 & 0.42 & 0.50 & 0.48 & 1.1 & 2.1 & $31 / 24$ & SKY, $\mathrm{CHK}_{\mathrm{EW}}, \mathrm{OCM}_{1}$ \\
\hline
\end{tabular}

Note: " +1 " = tree ring growth in the following year; $\mathrm{CHK}=$ Choctawhatchee Ringwidth; $\mathrm{CHK}_{\mathrm{EW}}=$ Choctawhatchee Earlywood; $\mathrm{EBE}=$ Ebenezer Creek; $\mathrm{IOL}_{1}=$ Iola Lake $+1 ; \mathrm{OCM}_{1}=$ Ocmulgee River $+1 ; \mathrm{PNC}_{1}=$ Piney Creek; SKY = Sky Lake; SUW = Suwannee River; $R^{2}=$ Variance in the data that is explained by the model, $R^{2}(p)=R^{2}$ (predicted) is a measure of how well the model predicts new observations, $R^{2}$ adj variance explained adjusted for multiple predictors; VIF = Variance Inflation Factor is a measure of the correlation between predictors, $\mathrm{D}-\mathrm{W}=$ Durbin-Watson statistic is a measure of autocorrelation in residuals.

The model adds and removes predictors until all variables not in the model have $p$-values that are greater than the specified alpha-to-enter value, and when all variables in the model have $p$-values that are less than or equal to the specified alpha-to-remove value. Following the procedure of Woodhouse et al. [21], the F-level for a predictor chronology had to have a maximum $p$-value of 0.05 for entry and 0.10 for retention in our stepwise regression model.

Standard statistical measures were used to establish the statistical skill of each streamflow reconstruction [32]. The $\mathrm{R}^{2}$ value quantified the amount of variance in each model. The $\mathrm{R}^{2}$ - predicted was calculated in Minitab using leave-one-out-cross-validation, in which a single year or observation is removed when fitting the model.

As a result, the prediction errors are independent of the predicted value at the removed observation [59]. The Variation Inflation Factor (VIF) indicates the extent to which 
multicollinearity is present in a regression analysis. Generally, a VIF value close to 1.0 indicates low correlation between predictors and is ideal for a regression model [60]. The Durbin-Watson (D-W) statistic was used to analyze the autocorrelation structure of model residuals [61]. The sign test, a nonparametric procedure to count the number of agreements and disagreements between instrumental and reconstructed flow, was used for additional model validation.

After reconstruction models were established, quantile mapping bias correction was performed via the "RQUANT" method in the qmap package in R [62,63], as described in Robeson et al. [64]. The bias-corrected reconstructions for the three downstream gages (Choctawhatchee at Bruce, Escambia, and Perdido) were then standardized for comparison.

For comparison to a river system outside of the AL-FL intrastate system, and to better understand the potential hydroclimatic drivers throughout the region, a streamflow reconstruction was also performed following the same techniques for the Pascagoula River gage in Merrill, MS west of our study area (Figure 1; Tables 1 and 2). Like all other reconstructions in this study, streamflow reconstructions for the Pascagoula River were standardized and bias corrected, and therefore made comparable to the recent observed period (post-1980s CE), as well as the reconstructions of intrastate rivers along the ALFL border.

\section{Results}

After correlation, the TRCs containing positive, significant R-values $(p \leq 0.05)$ were retained. The number of retained TRCs varied by streamflow gage, but out of the original 148 TRCs, 14 TRCs were retained in the Perdido River, 17 were retained in the Choctawhatchee River (at Bruce, FL), 20 were retained in the Escambia River, and 21 were retained in the Choctawhatchee River (at Newton, AL) and Conecuh correlation analyses. Following the stability analysis (30-year window), the final number of chronologies introduced into the stepwise linear regression model remained the same, ranging from 14 to 21 .

For all streamflow gages, the best calibration models and reconstructions (based on the length of the record and overall statistical skill) were chosen (Table 3). The calibration models listed in Table 3 were statistically skillful $\left(R^{2} \geq 0.50\right)$. The $D-W$ test for autocorrelation in the residuals from the regression showed that the autocorrelation was not significant for any of the models, indicating that the residuals were random, and the models were appropriate [65]. VIF values for all models were within the acceptable ranges (1.0-1.2) and the sign test results were insignificant $(p \geq 0.10)$ for all the calibration models, indicating that the models were balanced with no significant bias.

TRCs retained by the calibration models were distributed across the Southeast, and five of the eight retained TRCs were Taxodium distichum (L.) Rich. (bald cypress; Table 3). As the longest-lived tree species in eastern North America, T. distichum has been shown to provide a valuable annual archive of multi-millennial paleo-hydroclimate conditions [3,8,9,14,29,31], and thus is ideal for developing these long reconstructions. Three TRCs were retained in the Choctawhatchee (Newton), Conecuh and Escambia River models, and two were retained by the Choctawhatchee (Bruce) and Perdido River models.

All five streamflow gages demonstrate comparable patterns in their reconstructions, indicating a common climatic pattern in the AL-FL region (Figures $2 \mathrm{a}-\mathrm{c}$ and 3 ). At all four gages reconstructed to the early 1800s, a notable pluvial event was observed in the reconstruction ca. $1830 \mathrm{CE}$, followed shortly after by a severe drought in the mid1800s. All five reconstructions end prior to the end of the observed records and cannot be compared to more recently observed data without bias correction [64]. Therefore, the initial streamflow reconstruction values were bias-corrected. The bias-corrected data for the downstream gages along the rivers located in Florida (Choctawhatchee at Bruce, Escambia, and Perdido) were then standardized such that they could be compared against each other (Figure 3; [63]). 


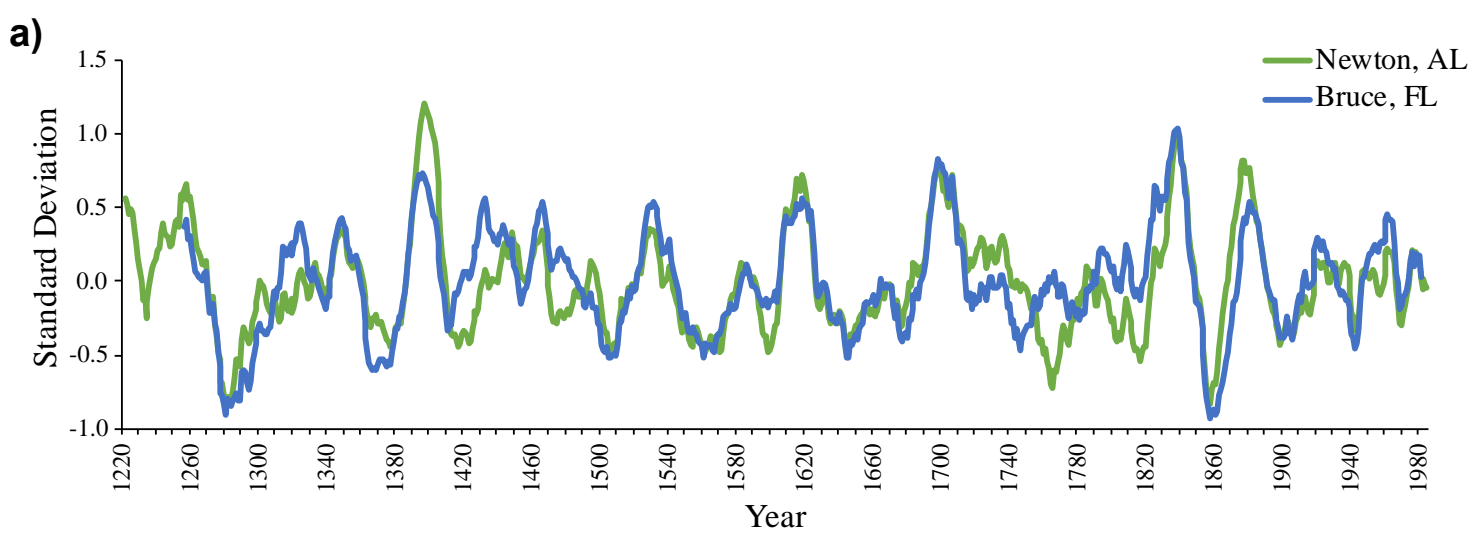

b)
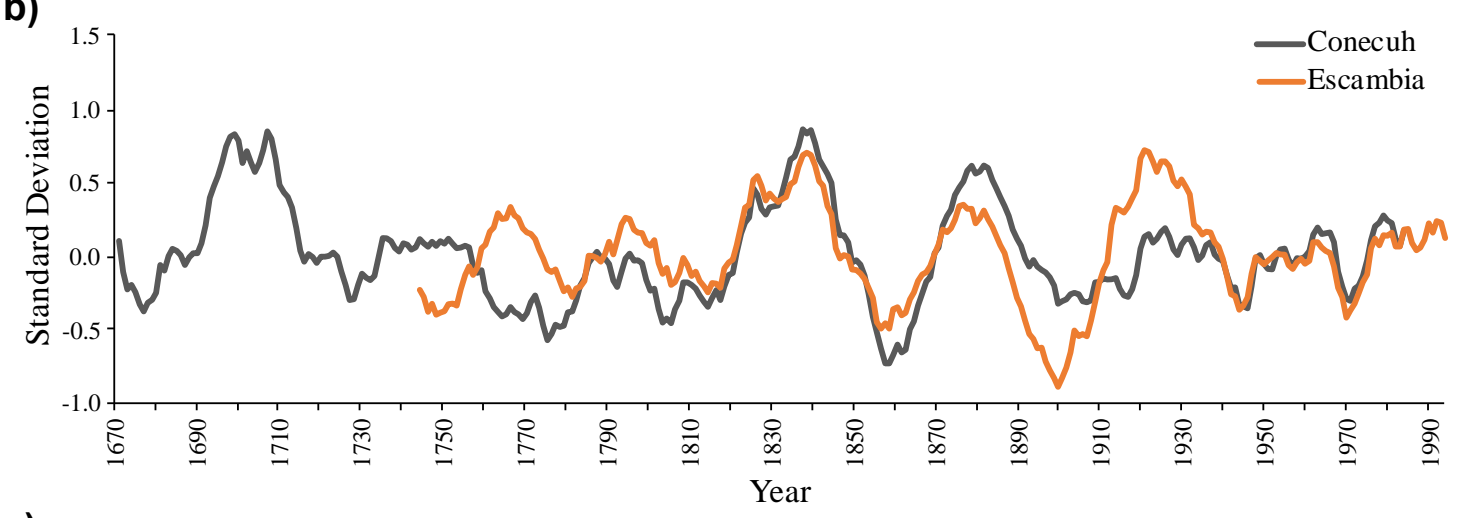

c)

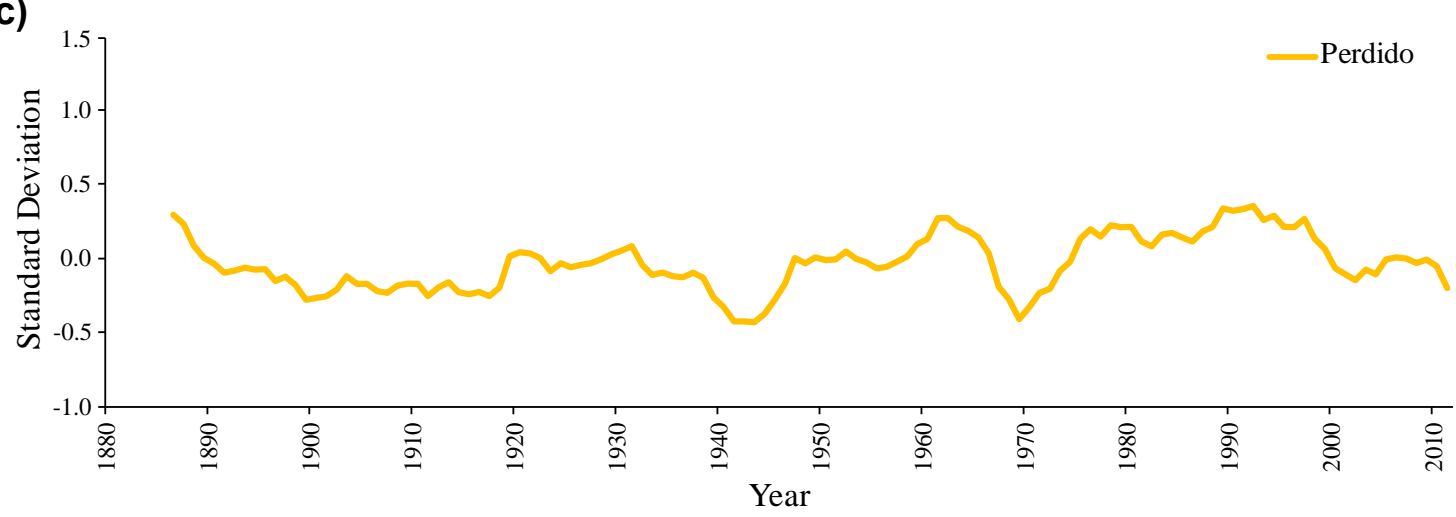

Figure 2. Standardized streamflow reconstructions for the (a) Choctawhatchee River at gages in Newton, AL (1222-1985) and Bruce, FL (1257-1982), (b) Conecuh River (1671-1983) and Escambia River (1744-1993), and (c) Perdido River (1885-2011). All datasets have been smoothed with a 20-year-end-year running mean. For full time scale see Figure A1.

The Conecuh and Choctawhatchee at Newton gages were not included in this analysis because the Conecuh streamflow is highly correlated with the Escambia gage, and the Choctawhatchee at Newton streamflow is highly correlated with the Choctawhatchee at Bruce gages. The three downstream gages followed a very similar pattern over the overlapping 150 year period. Despite a recovery in streamflow in the 1990s in the Perdido River, all three rivers appear to be in a drought state now, as the streamflow has been below average for the last 20-30 years (Figure 3a,b).

For comparison, the Pascagoula river gage near Merrill, MS is presented relative to the three other streamflow reconstructions for the AL-FL rivers (Figure 3). Unlike the rivers along the AL-FL border, the Pascagoula River has demonstrated a recovery in streamflow over the last 20-30 years (Figure 3), indicating a potential divide in the hydro-climatological conditions east and west of the MS-AL border. 

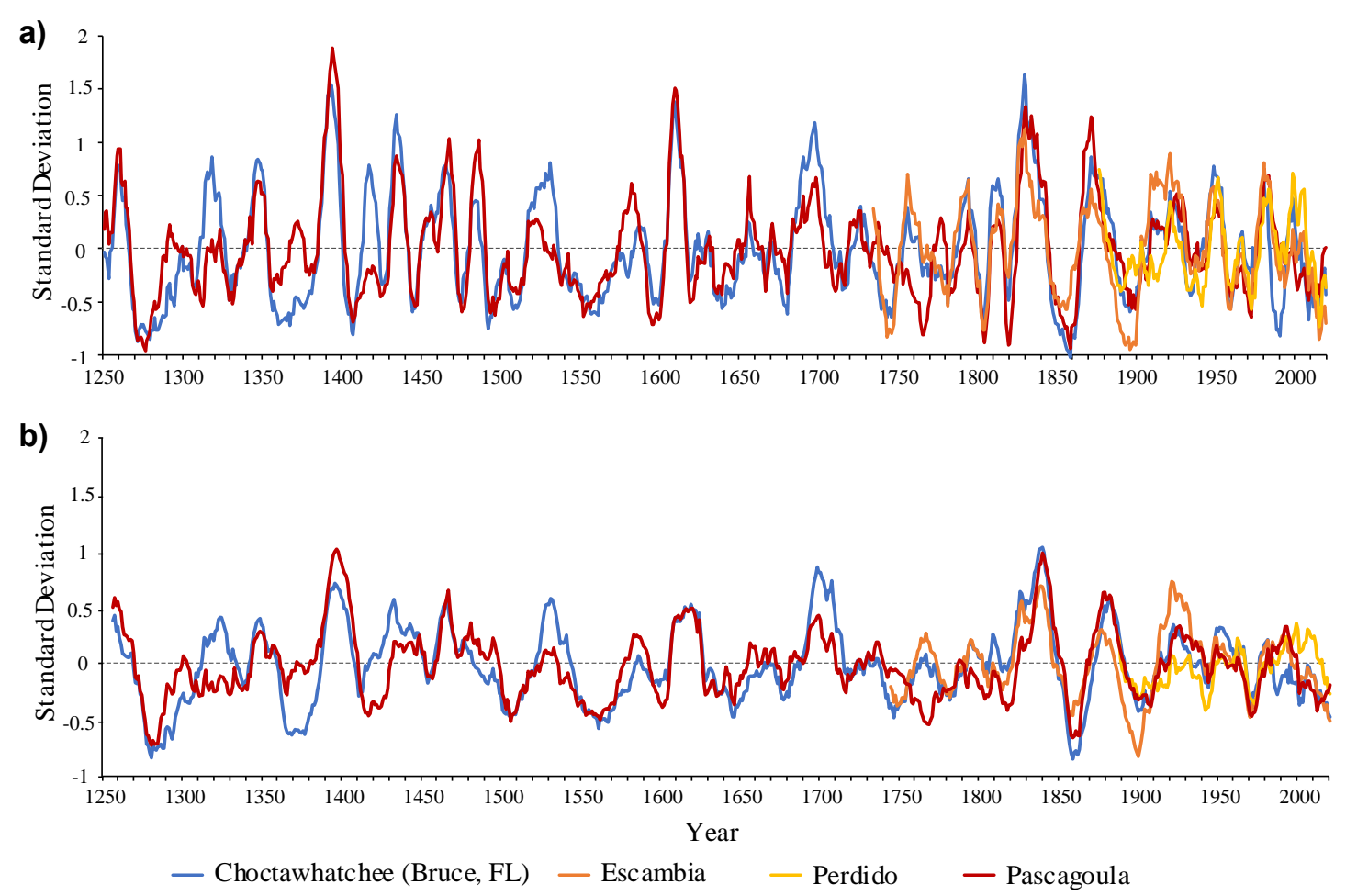

Figure 3. Bias corrected and standardized reconstructed and observed streamflow for the Choctawhatchee, Escambia, Perdido, and Pascagoula rivers (1238-2019) smoothed with a (a) 10-year end-year filter (1247-2019) and (b) 20-year end-year filter (1257-2019).

\section{Discussion}

Clear patterns in hydroclimatic regimes emerge from the streamflow reconstructions in each of these different rivers, as all five of the reconstructions indicate similar hydroclimatic extremes within the paleo-record. As indicated in the bias-corrected 10- and 20-year filtered reconstruction data (Figure $3 a, b$ ) periods of multi-year pluvial activity are indicated in the 1390 s, 1600 s to 1610 s, 1690 s to 1700 s, 1820 s to 1840 s (including the 1830 CE event) and 1860 s to 1880 s. While streamflow reconstructions that extend back to the early 1300 s are limited within the region, historical and reconstructed records from rivers in Florida and Georgia show that the late 17th century and the early and late 19th century experienced intense pluvial periods $[12,14,30,34]$.

While periods of intense pluvial events are clearly present within the reconstructions, multi-year droughts are indicated throughout the record and are validated by other similar findings throughout the region. Two of the more extreme periods of dryness and drought within the record occur between 1840-1860 and 1890-1910. The period from 1840-1860 is identified regionally $[14,66]$ and is of particular interest due to the abrupt shift in hydroclimatic conditions from intense drought to extreme moisture and pluvials in the later 1860s. The subsequent period of drought from 1890-1910 marks a period of dryness noted in multiple hydroclimate reconstructions throughout the Southeastern US [3,14,34]. Climate models presented in Herweijer et al. [67] indicate that this period of extreme drought is likely a response to cool tropical Pacific sea surface temperature (SST) forcing.

The recent drought (since ca. 2000 CE) in the Choctawhatchee, Escambia, and Perdido Rivers ranks as one of the most severe in the reconstructed paleo record. At each gage, we identified a recent 10-year drought period, and by ranking percentiles we determined the top 5\%. The 2008 CE (1999-2008) drought in the Choctawhatchee River and the 2015 CE (2006-2015) and 2016 CE (2007-2016) droughts in the Escambia and Perdido Rivers ranked in the top $5 \%$ of the driest periods in the reconstruction, only exceeded by droughts in the mid- and late-19th century. When examining the 20-year filtered results, the Conecuh, Escambia, and Perdido reconstructions again display a notable decline since $2000 \mathrm{CE}$, with several 20-year drought periods ending since 2000 in the top $10 \%$ of the driest periods. 
This period of multi-decadal streamflow decline has been observed throughout other states in the Southeastern US and appears to be associated with the confluence of multiple La Niña events (4) during a warm phase of the Atlantic Multidecadal Oscillation (AMO), with an inverse relationship between mid-Atlantic SST and streamflow over the same period [46]. Multiple studies have shown the association between Southeastern US water resources and AMO, ENSO, and PDO conditions [1,36-43], indicating the influence of both high and low frequency climate teleconnections within the region.

Interestingly, the Pascagoula River displays a strong recovery in streamflow during the 2000s when compared to the AL-FL interstate rivers in both the 10-year and 20-year end-filter analyses. This finding is consistent with Ho et al. [68], which suggests that a shift in climate exists along the Alabama-Mississippi state border. It is possible that increased moisture is found in the western regions of the Gulf of Mexico's coastal rivers compared to the eastern regions, as the eastern regions are more likely to be influenced by the western flank of the North Atlantic subtropical high (NASH; $[69,70])$. Further work investigating the hydroclimatic drivers and teleconnections is needed to elucidate the spatial variability in streamflow conditions across the Northern Gulf of Mexico. The end dates of these reconstructions reaffirm the need for new and updated TRCs in the studied region. To develop strong correlations and reconstruction models and to better predict streamflow variability, it is imperative that the International Tree Ring Databank (ITRDB) be continually updated and expanded. The new and updated chronologies developed and used within this work are part of an ongoing effort by multiple research teams to update and add new chronologies to the ITRDB [71-73]. Additionally, most reconstructions currently published in the region do not extend past the early 2000s [14,30]. For example, a reconstruction of the Suwannee River in Florida, east of our study area [14], demonstrated evidence of low streamflow in the Suwannee River since 2000, but the article did not discuss data more recent than 2005 CE. Thus, the Suwannee reconstruction cannot be compared to the 2015 CE drought observed in this study. Similarly, Pederson et al. [30] reconstructed drought in the Apalachicola-Chattahoochee-Flint river basin. This study demonstrated evidence of drought since 2000, but the reconstruction ended in 2010, so the period from 2010-2019 is not observed.

\section{Conclusions}

A multi-decadal decline in streamflow has been observed throughout the Southeastern US since the start of the 21st century. In this work, we show that relative to our nearly 800 year reconstructions of streamflow in the Choctawhatchee, Escambia, and Perdido Rivers, the last 20 years have had droughts ranking among some of the most severe in the reconstructed paleo record. In the 10-year filtered data, drought periods in the Choctawhatchee (1999-2008), the Escambia (2006-2015) and the Perdido Rivers (2007-2016) ranked among the driest periods (top $5 \%$ ) in the reconstruction, exceeded only by historic droughts in the 19th century. Similarly, in the 20-year filtered results, several streamflow reconstructions show that declining streamflow and drought over the past two decades have resulted in one of the lowest flow periods in the record (top 10\%). Given that the streams in this study have been identified by the USGS as "unimpaired" and have minimal anthropogenic impacts (such as consumptive extraction), our findings suggest that the rivers in this work are experiencing significant climate-driven declines in streamflow. These results are consistent with the findings of other studies throughout the southeastern US, which show this multidecadal decline associated with the interactions of both high-(La Niña) and low- (AMO, PDO) frequency climate teleconnections [14,36-43,46].

Knowledge of previous years' droughts and pluvial events is critical when making water policy decisions. With the combined stressors of population growth, interstate water wars, and climate change, it is imperative for Florida water managers and planners to have a full understanding of hydrologic parameters in the region. Instrumental observations for the five streamflow gages used in this study began in the 1930s-1940s CE, but the statistically skillful reconstructions presented in this study provide insight into streamflow as far back as the 1200s CE. We recommend additional paleo-reconstructions of interstate 
and coastal rivers in the southeastern United States be conducted to provide more insight into historical climate patterns and associated climate drivers in this region.

Author Contributions: M.V., conceptualization, data analysis, original draft preparation, review and editing; J.C., data analysis, original draft preparation, review and editing; G.T., conceptualization, field collection, acquisition of local hydrologic data, review and editing, funding acquisition; L.T., draft preparation, review and editing; E.E., draft preparation, review and editing, funding acquisition; G.L.H. conceptualization, field collection, tree-ring chronology development, review and editing, funding acquisition; J.K. review and editing, funding acquisition; S.S., data analysis. M.T., conceptualization, field collection, tree-ring chronology development, review and editing, funding acquisition. All authors have read and agreed to the published version of the manuscript.

Funding: This research was supported by NOAA Mississippi Alabama Sea Grant Consortium, (USM-GRO05007-R/RCE-05), the U.S. Environmental Protection Agency Gulf of Mexico Program (EPA-MX-00D67718-0), and the U.S National Science Foundation Paleo Perspectives on Climate Change, P2C2 Program (18059590).

Data Availability Statement: All streamflow data are available from the United States Geological Survey via the National Water Information System (http:/ / waterdata.usgs.gov/nwis/sw) and all tree-ring data are available from the International Tree-Ring Data Bank (https:/ / www.ncdc.noaa. gov/data-access/paleoclimatology-data/datasets/tree-ring).

Conflicts of Interest: The authors declare no conflict of interest. The funders had no role in the design of the study; in the collection, analyses, or interpretation of data; in the writing of the manuscript, or in the decision to publish the results.

\section{Appendix A}
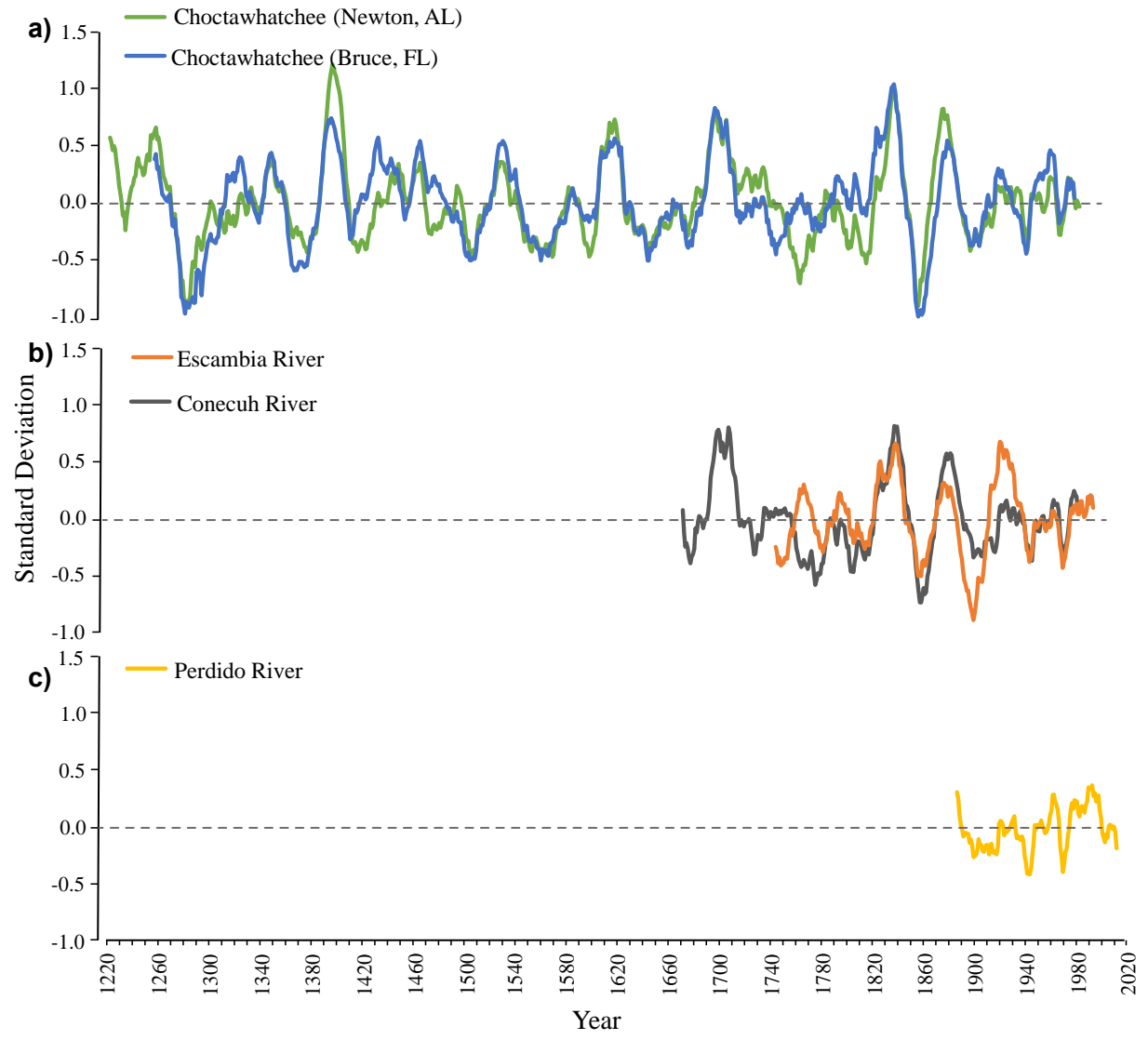

Figure A1. Comparison over the full reconstruction period of standardized streamflow reconstructions for the (a) Choctawhatchee River at gages in Newton, AL (1222-1985) and Bruce, FL (1257-1982), (b) Conecuh River (1671-1983) and Escambia River (1744-1993), and (c) Perdido River (1885-2011). All datasets have been smoothed with a 20-year-end-year running mean. 


\section{References}

1. Tootle, G.A.; Piechota, T.C. Suwannee River Long Range Streamflow Forecasts Based on Seasonal Climate Predictors. J. Am. Water Resour. Assoc. 2004, 40, 523-532. [CrossRef]

2. Crockett, K.; Martin, J.B.; Grissino-Mayer, H.D.; Larson, E.R.; Mirti, T. Assessment of Tree Rings as a Hydrologic Record in a Humid Subtropical Environment. J. Am. Water Resour. Assoc. 2010, 46, 919-931. [CrossRef]

3. Stahle, D.W.; Cleaveland, M.K. Reconstruction and Analysis of Spring Rainfall over the Southeastern U.S. for the Past 1000 Years. Bull. Am. Meteorol. Soc. 1992, 73, 1947-1961. [CrossRef]

4. Cook, E.; Meko, D.M.; Stahle, D.W.; Cleaveland, M. Drought reconstructions for the continental United States. J. Clim. 1999, 12, 1145-1162. [CrossRef]

5. Woodhouse, C.A.; Lukas, J.J. Multi-Century Tree-Ring Reconstructions of Colorado Streamflow for Water Resource Planning. Clim. Chang. 2006, 78, 293-315. [CrossRef]

6. Meko, D.M.; Woodhouse, C.A.; Baisan, C.A.; Knight, T.; Lukas, J.J.; Hughes, M.K.; Salzer, M.W. Medieval drought in the upper Colorado River Basin. Geophys. Res. Lett. 2007, 34, 10705. [CrossRef]

7. Derose, R.; Bekker, M.F.; Wang, S.-Y.; Buckley, B.M.; Kjelgren, R.; Bardsley, T.; Rittenour, T.M.; Allen, E. A millennium-length reconstruction of Bear River stream flow, Utah. J. Hydrol. 2015, 529, 524-534. [CrossRef]

8. Stahle, D.W.; Edmondson, J.R.; Howard, I.M.; Robbins, C.R.; Griffin, R.D.; Carl, A.; Torbenson, M.C.A. Longevity, climate sensitivity, and conservation status of wetland trees at Black River, North Carolina. Environ. Res. Commun. 2019, 1, 041002. [CrossRef]

9. Stahle, D.W.; Cleaveland, M.K.; Hehr, J.G. North Carolina Climate Changes Reconstructed from Tree Rings: A.D. 372 to. Science 1988, 240, 1517-1519. [CrossRef] [PubMed]

10. Cleaveland, M.K. A 963-year reconstruction of summer (JJA) stream flow in the White River, Arkansas, USA, from tree-rings. Holocene 2000, 10, 33-41. [CrossRef]

11. Stahle, D.W.; Fye, F.K.; Therrell, M.D. Interannual to decadal climate and streamflow variability estimated from tree rings. Dev. Quat. Sci. 2003, 1, 491-504. [CrossRef]

12. Seager, R.; Tzanova, A.; Nakamura, J. Drought in the Southeastern United States: Causes, Variability over the Last Millennium, and the Potential for Future Hydroclimate Change*. J. Clim. 2009, 22, 5021-5045. [CrossRef]

13. Cook, E.R.; Palmer, J.G.; Ahmed, M.; Woodhouse, C.A.; Fenwick, P.; Zafar, M.U.; Wahab, M.; Khan, N. Five centuries of Upper Indus River flow from tree rings. J. Hydrol. 2013, 486, 365-375. [CrossRef]

14. Harley, G.L.; Maxwell, J.T.; Larson, E.; Grissino-Mayer, H.D.; Henderson, J.; Huffman, J. Suwannee River flow variability 1550-2005 CE reconstructed from a multispecies tree-ring network. J. Hydrol. 2017, 544, 438-451. [CrossRef]

15. Maxwell, R.S.; Harley, G.L.; Maxwell, J.T.; Rayback, S.A.; Pederson, N.; Cook, E.R.; Barclay, D.J.; Li, W.; Rayburn, J.A. An interbasin comparison of tree-ring reconstructed streamflow in the eastern United States. Hydrol. Process. 2017, 31, 2381-2394. [CrossRef]

16. Stockton, C.; Jacoby, G. Long-term Surface-water Supply and Streamflow Levels in the Upper Colorado River Basin. Lake Powell Res. Proj. Bull. 1976, 18, 70.

17. Meko, D.M.; Graybill, D.A. Tree-ring reconstruction of upper Gila River discharge. J. Am. Water Resour. Assoc. 1995, 31, 605-616. [CrossRef]

18. Meko, D.M.; Therrell, M.D.; Baisan, C.H.; Hughes, M.K. sacramento river flow reconstructed to a.d. 869 from tree rings. J. Am. Water Resour. Assoc. 2001, 37, 1029-1039. [CrossRef]

19. Gray, S.T.; Fastie, C.L.; Betancourt, J.L.; Jackson, S.T. Patterns and sources of multidecadal oscillations in drought-sensitive tree-ring records from the central and southern Rocky Mountains. Geophys. Res. Lett. 2003, 30, 491-494. [CrossRef]

20. Gray, S.T.; Jackson, S.T.; Betancourt, J.L. Tree-Ring Based Reconstructions of Interannual to Decadal Scale Precipitation Variability For Northeastern Utah Since. J. Am. Water Resour. Assoc. 2004, 40, 947-960. [CrossRef]

21. Woodhouse, C.A.; Gray, S.T.; Meko, D.M. Updated streamflow reconstructions for the Upper Colorado River ba-sin. Water Resour. Res. 2006, 42. [CrossRef]

22. Timilsena, J.; Piechota, T.C.; Hidalgo, H.; Tootle, G. Five Hundred Years of Hydrological Drought in the Upper Colorado River Basin. JAWRA 2007, 43, 798-812. [CrossRef]

23. Watson, T.A.; Barnett, F.A.; Gray, S.T.; Tootle, G.A. Reconstructed Streamflows for the Headwaters of the Wind River, Wyoming, United States. JAWRA 2009, 45, 224-236. [CrossRef]

24. Barnett, F.A.; Gray, S.T.; Tootle, G.A. Upper Green River Basin (United States) Streamflow Reconstructions. J. Hydrol. Eng. 2010, 15, 567-579. [CrossRef]

25. Wise, E.K. Tree ring record of streamflow and drought in the upper Snake River. Water Resour. Res. 2010, 46. [CrossRef]

26. Margolis, E.Q.; Meko, D.M.; Touchan, R. A tree-ring reconstruction of streamflow in the Santa Fe River, New Mexico. J. Hydrol. 2011, 397, 118-127. [CrossRef]

27. Anderson, S.; Moser, C.L.; Tootle, G.A.; Grissino-Mayer, H.D.; Timilsena, J.; Piechota, T. Snowpack Reconstructions Incorporating Climate in the Upper Green River Basin (Wyoming). Tree-Ring Res. 2012, 68, 105-114. [CrossRef]

28. Anderson, S.; Tootle, G.A.; Grissinomayer, H.D. Reconstructions of Soil Moisture for the Upper Colorado River Basin Using Tree-Ring Chronologies. J. Am. Water Resour. Assoc. 2012, 48, 849-858. [CrossRef] 
29. Stahle, D.W.; Cleaveland, M.K. Tree-ring reconstructed rainfall over the southeastern U.S.A. during the medieval warm period and little ice age. Clim. Chang. 1994, 26, 199-212. [CrossRef]

30. Pederson, N.; Bell, A.R.; Knight, T.A.; Leland, C.; Malcomb, N.; Anchukaitis, K.J.; Tackett, K.; Scheff, J.; Brice, A.; Catron, B.; et al. A long-term perspective on a modern drought in the American Southeast. Environ. Res. Lett. 2012, 7, 014034. [CrossRef]

31. Therrell, M.D.; Elliott, E.A.; Meko, M.D.; Bregy, J.C.; Tucker, C.S.; Harley, G.L.; Maxwell, J.T.; Tootle, G.A. Streamflow Variability Indicated by False Rings in Bald Cypress (Taxodium distichum (L.) Rich.). Forests 2020, 11, 1100. [CrossRef]

32. Anderson, S.; Ogle, R.; Tootle, G.; Oubeidillah, A. Tree-Ring reconstructions of streamflow for the Tennessee val-ley. Hydrology 2019, 6, 34. [CrossRef]

33. Bregy, J.C.; Roberts, T.; Elliott, E.A.; Therrell, M.D.; Lampman, C.R.; Maxwell, J.T.; Harley, G.L. Utilizing Anatomical Anomalies in Taxodium Distichum to Reconstruct Tropical Cyclone Activity along the Northern Gulf of Mexico; American Geophyiscal Union: Washington, DC, USA, 2019; PP11C-1397.

34. Kam, J.; Tootle, G.A.; Therrell, G.A.; Elliott, E.A. Future Streamflow in a Southeastern US watershed from a Paleo Perspective: A case study of St. Marys River, Florida. In Proceedings of the 34th Coneference on Climate Variability and Change at 101st American Meteorological Society Annual Meeting, 10-15 January 2021. (Virtual Meeting).

35. McCabe, G.J.; Wolock, D.M. Spatial and temporal patterns in conterminous United States streamflow characteristics. Geophys. Res. Lett. 2014, 41, 6889-6897. [CrossRef]

36. McCabe, G.J.; Palecki, M.A.; Betancourt, J.L. Pacific and Atlantic Ocean influences on multidecadal drought frequency in the United States. Proc. Natl. Acad. Sci. USA 2004, 101, 4136-4141. [CrossRef] [PubMed]

37. Tootle, G.A.; Piechota, T.C.; Singh, A.K. Coupled oceanic/atmospheric variability and United States streamflow. Water Resour. Res. 2005, 41, W12408.

38. Johnson, N.T.; Martinez, C.J.; Kiker, G.A.; Leitman, S. Pacific and Atlantic sea surface temperature influences on streamflow in the Apalachicola-Chattahoochee-Flint river basin. J. Hydrol. 2013, 489, 160-179. [CrossRef]

39. Kam, J.; Sheffield, J. Changes in the low flow regime over the eastern United States (1962-2011): Variability, trends, and attributions. Clim. Chang. 2016, 135, 639-653. [CrossRef]

40. Wang, H.; Asefa, T. Impact of different types of ENSO conditions on seasonal precipitation and streamflow in the Southeastern United States. Int. J. Clim. 2018, 38, 1438-1451. [CrossRef]

41. Engström, J.; Waylen, P. Drivers of long-term precipitation and runoff variability in the southeastern USA. Theor. Appl. Clim. 2017, 131, 1133-1146. [CrossRef]

42. Maleski, J.J.; Martinez, C.J. Coupled impacts of ENSO AMO and PDO on temperature and precipitation in the Alabama-CoosaTallapoosa and Apalachicola-Chattahoochee-Flint river basins. Int. J. Clim. 2018, 38, e717-e728. [CrossRef]

43. Sadeghi, S.G.; Tootle, E.; Elliott, V.; Lakshmi, M.; Therrell, J.K.; Bearden, B. Atlantic Ocean Sea Surface Tem-peratures and Southeast United States streamflow variability: Associations with the recent multi-decadal decline. J. Hydrol. 2019, 576, 422-429. [CrossRef]

44. Bureau, US Census. State Population Totals: 2010-2019. The United States Census Bureau. Available online: www.census.gov/ data/tables/time-series/demo/popest/2010s-state-total.html (accessed on 30 December 2019).

45. Bearden, B.L.; Andreen, W.L. Update on the Tri-State Water Wars. Wave 2017, 37, 15-21.

46. Sheffield, J.; Wood, E.F. Projected changes in drought occurrence under future global warming from multi-model, multi-scenario, IPCC AR4 simulations. Clim. Dyn. 2008, 31, 79-105. [CrossRef]

47. National Weather Information System (NWIS): USGS surface-water data for the nation. Available online: http:/ / waterdata.usgs. gov/nwis/sw (accessed on 16 June 2020).

48. ITRDB (International Tree Ring Data Bank). Tree-Ring Data Search. Available online: https://www.ncdc.noaa.gov/data-access/ paleoclimatology-data/datasets / tree-ring (accessed on 20 June 2020).

49. Fritts, H.C. Tree Rings and Climate; Academic Press: New York, NY, USA, 1976; p. 567.

50. Biondi, F.; Waikul, K. DENDROCLIM2002: A C++ program for statistical calibration of climate signals in tree-ring chronologies. Comput. Geosci. 2004, 30, 303-311. [CrossRef]

51. Stahle, D.W.; Cleaveland, M.K. (2002-04-26): NOAA/WDS Paleoclimatology-Stahle-Choctawhatchee River-TADI-ITRDB FL001. [all]. NOAA National Cen-ters for Environmental Information. Available online: https://www.ncdc.noaa.gov/paleo-search/ study/4830 (accessed on 1 June 2020).

52. Stahle, D.W. (2002-04-26): NOAA/WDS Paleoclimatology-Stahle-Ebenezer Creek-TADI-ITRDB GA003. [all]. NOAA National Centers for Environmental Information. Available online: https:/ / www.ncdc.noaa.gov/paleo-search/study/4842 (accessed on 1 June 2020).

53. Stahle, D.W. (2002-04-26): NOAA/WDS Paleoclimatology-Stahle-Ocmulgee River-TADI-ITRDB GA004. [all]. NOAA National Centers for Environmental Information. Available online: https:/ / www.ncdc.noaa.gov/paleo-search/study/4913 (accessed on 1 June 2020).

54. Stahle, D.W.; Cook, E.R.; Burnette, D.J.; Villanueva, J.; Cerano, J.; Burns, J.N.; Griffin, D.; Cook, B.I.; Acuña, R.; Torbenson, M.C.; et al. The Mexican Drought Atlas: Tree-ring reconstructions of the soil moisture balance during the late pre-Hispanic, colonial, and modern eras. Quat. Sci. Rev. 2016, 149, 34-60. [CrossRef] 
55. Duvick, D.N. (2002-04-26): NOAA/WDS Paleoclimatology-Duvick-Piney Creek Pocket Wilderness-QUAL-ITRDB TN005. [all]. NOAA National Centers for Environmental Information. Available online: https://www.ncdc.noaa.gov/paleo-search/study/31 78 (accessed on 1 June 2020).

56. Stahle, D.W.; Cleaveland, M.K.; Sierzchula, S. (2005-08-25): NOAA/WDS Paleoclimatology-Stahle-Suwannee River-QULY-ITRDB FL005. [all]. NOAA National Centers for Environmental Information. Available online: https://www.ncdc.noaa.gov/paleosearch/study/4948 (accessed on 1 June 2020).

57. Maxwell, J.T.; Knapp, P.A.; Ortegren, J.T. Influence of the Atlantic Multidecadal Oscillation on tupelo honey production from AD 1800 to. Agric. For. Meteorol. 2013, 174, 129-134. [CrossRef]

58. Stahle, D.W.; Therrell, M.D.; Cleaveland, M.K. (2002-04-26): NOAA/WDS Paleoclimatology-Stahle-Pascagoula River-TADIITRDB MS002. [all]. NOAA National Centers for Environmental Information. Available online: https:/ /www.ncdc.noaa.gov/ paleo-search/study/4917 (accessed on 1 June 2020).

59. Garen, D.C. Improved Techniques in Regression-Based Streamflow Volume Forecasting. J. Water Resour. Plan. Manag. 1992, 118, 654-670. [CrossRef]

60. O'Brien, R.M. A Caution Regarding Rules of Thumb for Variance Inflation Factors. Qual. Quant. 2007, 41, 673-690. [CrossRef]

61. Durbin, J.; Watson, G.S. Testing for serial correlation in least squares regression: I. Biometrika 1950, 37, 409-428.

62. R Core Team R: A Language and Environment for Statistical Computing. R Foundation for Statistical Computing, Vienna, Austria. Available online: http:/ / www.R-project.org/ (accessed on 1 June 2020).

63. Gudmundsson, L.; Bremnes, J.B.; Haugen, J.E.; Engen-Skaugen, T. Downscaling RCM precipitation to the station scale using statistical transformations-A comparison of methods. Hydrol. Earth Syst. Sci. 2012, 16, 3383-3390. [CrossRef]

64. Robeson, S.M.; Maxwell, J.T.; Ficklin, D.L. Bias Correction of Paleoclimatic Reconstructions: A New Look at 1,200+ Years of Upper Colorado River Flow. Geophys. Res. Lett. 2020, 47, e2019GL086689. [CrossRef]

65. Draper, N.R.; Smith, H. Applied Regression Analysis, 2nd ed.; John Wiley: New York, NY, USA, 1981; p. 736.

66. Henderson, J. Dendroclimatological analysis and fire history of longleaf pine (Pinus palustris Mill.) in the Atlantic and Gulf Coastal Plain. Ph.D. Thesis, The University of Tennessee, Knoxville, TN, USA, 2006; p. 463.

67. Herweijer, C.; Seager, R.; Cook, E.R. North American droughts of the mid to late nineteenth century: A history, simulation and implication for Mediaeval drought. Holocene 2006, 16, 159-171. [CrossRef]

68. Ho, M.; Lall, U.; Sun, X.; Cook, E.R. Multiscale temporal variability and regional patterns in 555 years of conterminous U.S. streamflow. Water Resour. Res. 2017, 53, 3047-3066. [CrossRef]

69. Li, L.; Li, W.; Kushnir, Y. Variation of the North Atlantic subtropical high western ridge and its implication to Southeastern US summer precipitation. Clim. Dyn. 2011, 39, 1401-1412. [CrossRef]

70. Wei, W.; Li, W.; Deng, Y.; Yang, S. Intra-seasonal variation of the summer rainfall over the Southeastern United States. Clim. Dyn. 2019, 53, 1171-1183. [CrossRef] [PubMed]

71. Trouet, V.; Harley, G.L.; Domínguez-Delmás, M. Shipwreck rates reveal Caribbean tropical cyclone response to past radiative forcing. Proc. Natl. Acad. Sci. USA 2016, 113, 3169-3174. [CrossRef] [PubMed]

72. Tucker, C.S.; Trepanier, J.C.; Harley, G.L.; Delong, K.L. Recording Tropical Cyclone Activity from 1909 to 2014 along the Northern Gulf of Mexico using Maritime Slash Pine Trees (Pinus elliottii var. elliottii Engelm.). J. Coast. Res. 2018, 342, 328-340. [CrossRef]

73. Strange, B.M.; Maxwell, J.T.; Robeson, S.M.; Harley, G.L.; Therrell, M.D.; Ficklin, D.L. Comparing three approaches to reconstructing streamflow using tree rings in the Wabash River basin in the Midwestern, US. J. Hydrol. 2019, 573, 829-840. [CrossRef] 